\title{
突発性難聴における前庭症状と聴力回復
}

\author{
鰐㴊 伸子・石塚 洋一・前田 秀彦
}

\section{Vestibular Signs and Hearing Improvement in Sudden Deafness}

\author{
Nobuko Wanifuchi, Yoichi Ishizuka and Hidehiko Maeda \\ (Teikyo University School of Medicine, Mizonokuchi Hospital)
}

The authors studied 136 patients with sudden deafness over a 6 -year period, 44 patients with vestibular signs, such as vertigo or dizziness and 92 patients without vestibular signs.

Equilibrium function was abnormal in $70.5 \%$ of the patients with vestibular signs and in only $19.6 \%$ of those without vestibular signs, however, there was no significant difference between the two classes in pure-tone average improvement over $30 \mathrm{~dB}$.

Other relationships between the results of each examination and hearing improvement are discussed.

Key words: idiopathic sudden deafness, vestibular signs, equilibrium function

\section{はじめに}

突発性難聴の予後には，年齢，発症時の難聴 の程度，発症から治療開始までの期間などが関 与するといわれている。乙てまでにわれわれが 行った検討では，年齢ではとくに60歳以上で治 痛率は低く, 発症時 $30 \mathrm{~dB}$ 以内の軽度難聴例 や 7 日以内の早期治療開始例では予後良好であ った'1).

また突発性難聴ではめまいを訴えることがあ り，前庭症状の有無も予後を左右する重要な因 子と考えられている.

今回われわれは, 突発性難聴患者においてめ まいの有無がその予後に関与するか，めまいの 有無之平衡機能検査所見之相関するか, 平衡機 能検査の予後を推測する上での有用性について 検討を行ったので報告する.

\section{対象および方法}

対象は, 過去 6 年間に当科で入院加療を行っ た突発性難聴患者136例139耳で前庭症状として 発症時あるいは入院時にめまいを自覚した44例 （32.4\%，めまい有り群）とめまいを自覚しな かった92例95耳（めまい無し群）に分け，各々 の群について入院時に行った平衡機能検査所見 および治療成績について検討した. 平衡機能検 査としては, Frenzel 眼鏡下の頭位・頭位変換 眼振 (以下眼振と略す), ENG 検査（注視眼振, 誘発眼振, 視運動性眼振, 視標追跡検査, 温度 眼振の記録）重心動摇計記録を行い，乙れらの 平衡機能検査のうち 1 つでも異常所見を認めた あのを平衡機能検査所見有りとした. 重心動摇 計については重心動摇総軌跡距離と実効值が, 開眼および閉眼時のいずれも前田 ${ }^{2)}$ により呈示 
された正常範囲以外のものを異常と判定した。 眼振検查は全例, ENG 検査は73例, 重心動摇 計は58例に施行した.

治療方法は, ステロイド, ビタミン剤, 血管 拡張剤, ATP など薬物療法に星状神経節ブロッ ク（以下 $\mathrm{SGB}$ と略す）を併用したもの（SGB Đ群）と，ステロイドなどの薬物療法のみを行 ったもの ( $\mathrm{SGB} \ominus$ 群) の 2 群で，めまい有り 群では $\mathrm{SGB} \ominus$ 群21例, $\mathrm{SGB} \oplus$ 群23例, めまい 無し群では $\mathrm{SGB} \ominus$ 群48例， $\mathrm{SGB} \oplus$ 群44例であ った.

星状神経節ブロックは anterior approach 法 で, $1 \%$ 塩酸メピバカイン $8 \mathrm{ml}$ を使用し, 麻酔 科ペインクリニックにて原則として連日 2 回, 入院期間中継続して行った. 平均 SGB 回数は 27回であった。 また，ステロイドはプレドニソ ロンを漸減法にて点滴静注で使用した(表 1 ).

予後（聴力回復の程度）は厚生省の判定基準 に従い, 回復以上（5 周波数の算術平均值が $10 \mathrm{~dB}$ 以上改善）を「有効率」, 著明回復以上 （5 周波数の算術平均值 か $30 \mathrm{~dB}$ 以上改善）
を「改善率」，治癔したあの（5 周波数がすべ て $20 \mathrm{~dB}$ 以内に回復）を「治癒率」として治療 成績について検討を行った。 また有意差検定に は $\chi^{2}$ 検定を用いた。

\section{結 果}

1. 年齢分布は, めまい有り群では30歳代と 60 歳代にピークを認め, 平均年齿 44.6 歳で男性 29例，女性15例でやや男性に多い傾向が認めら

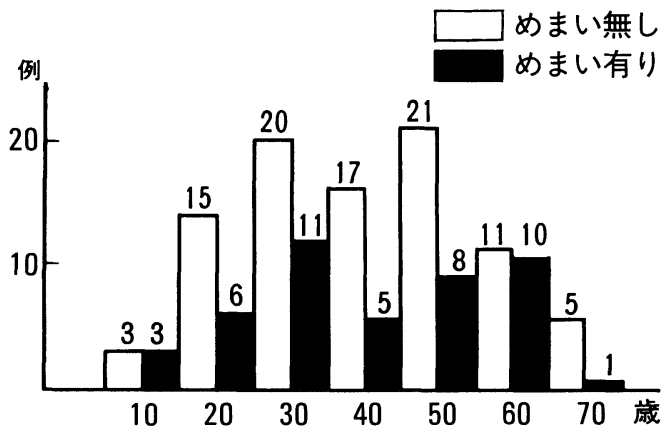

図1突発性難聴発症時の年秢および性別分布 めまい無し92例; 平均 44. 7歳, 男性 43例, 女性 49 例.

めまい有り 44例; 平均 44.6歳, 男性 29例, 女性15例.

表 1136 症例の内訳

\begin{tabular}{|c|c|c|c|}
\hline & & めまい無し & めまい有り \\
\hline \multicolumn{2}{|l|}{ 症例数 } & 92例（95耳） & 44例（44耳） \\
\hline \multirow[t]{2}{*}{ 性 別 } & 男性 & 43例 & 29例 \\
\hline & 女性 & 49 & 15 \\
\hline 平均年齡 & & 44.7 歲 & 44.6歳 \\
\hline \multirow{3}{*}{$\begin{array}{l}\text { 発症時の } \\
\text { 難聴の程度 }\end{array}$} & 軽 度 & 12耳 & 4 耳 \\
\hline & 中等度 & 34 & 11 \\
\hline & 高 度 & 49 & 29 \\
\hline \multirow{3}{*}{$\begin{array}{l}\text { 発症から治療 } \\
\text { 開始までの期間 }\end{array}$} & 7 日以内 & 80例 & 33例 \\
\hline & $8 \sim 14$ 日 & 8 & 7 \\
\hline & 15日以上 & 4 & 4 \\
\hline \multirow[t]{2}{*}{ 治療方法 } & SGB - & 48例 & 21 例 \\
\hline & SGB + & 44 & 23 \\
\hline
\end{tabular}


れた。 めまい無し群では30歳代と50歳代にピー クを認め, 平均年秢44.7歳で男性43例, 女性49 例で性差は認められなかった（図1）.

2. 発症から治療開始までの期間は，めまい 有り群で 7 日以内が33例，8〜14日以内が 7 例, 15日以上が 4 例，めまい無し群ではそれぞれ80 例，8例，4例で，両群と屯に90\%以上が14日 以内に治療を開始していた（表 1 ).

3. 発症時の難聴の程度を $250 \sim 4000 \mathrm{~Hz}$ ま での 5 周波数平均值が $0 \sim 30 \mathrm{~dB}$ を軽度, 31 $60 \mathrm{~dB}$ を中等度， $61 \mathrm{~dB}$ 以上を高度と分類する と，高度例がめまい有り群では29耳 (65.9\%), めまい無し群では49耳（53.3\%）で両群と屯高 度例が50\%以上を占めていた（図 2 ）。

4. めまい有り群次いて，めまいの性質を 回転性と非回転性に分けると，回転性めまい25

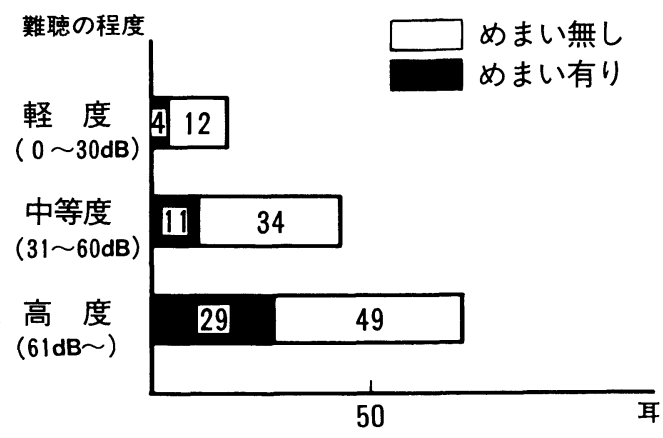

図2 めまいの有無と難聴の程度による分類 めまい無し95耳の中では高度難聴が49耳（53.3 \%)，めまい有り44耳の中では高度難聴が $29 耳$ (65. $9 \%)$ である.

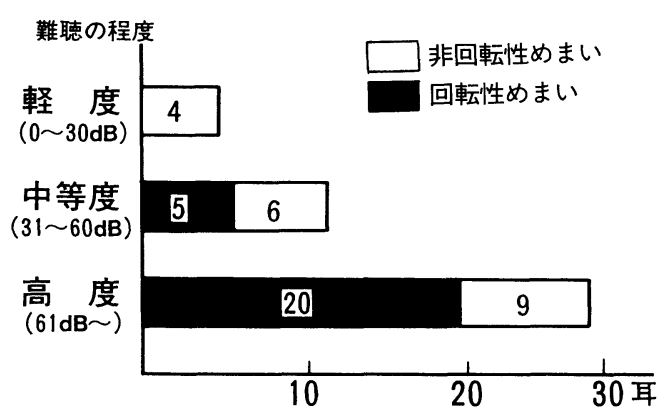

図 3 めまいの性質と発症時の難聴の程度 非回転性めまいは19耳，回転性めまいは25 耳である.
耳，非回転性めまい19耳であった。発症時の難 聴の程度では，非回転性めまいでは高度例は 9 耳で非回転性めまい全体の $47.4 \%$ あったが， 回転性めまいでは軽度例はなく，高度例が20耳 で回転性めまい全体の80\%を占めていた(図 3 ).

5. 平衡機能検査で所見有りの屯のは，めま い有り44耳のうち31耳(70.5\%)，めまい無し95 耳のうち19耳（19.6\%）とめまい有り群で有意 に多く，平衡機能検査別にみても，異常所見有 りは眼振ではめまい有り44耳のうち24耳（54.5 \%)，めまい無し95耳のうち11耳(11.6\%), ENG ではめまい有り $30 耳$ 耳うち10耳(33.3\%)，めま い無し43耳のうち 7 耳 $(16.3 \%)$, 重心動摇計で はめまい有り 29 耳のうち14耳 $(48.3 \%)$, めまい 無し29耳のうち 1 耳 $(3.4 \%)$ で, 異常所見の出 現率はめまい有り群で多く認められた（表 2 ).

6. めまい有り群の「有効率」(聴力改善に ついて回復以上; 5 周波数の算術平均值が 10 $\mathrm{dB}$ 以上改善） $77.3 \%$,「改善率」(聴力改善に ついて著明回復以上; 5 周波数の算術平均值が $30 \mathrm{~dB}$ 以上改善）は54. 5\%で，めまい無し群の

表 2 平衡機能検査における異常所見の出現率

\begin{tabular}{l|rr|rr}
\hline & \multicolumn{2}{|c|}{ めまい無し } & \multicolumn{2}{|c}{ めまい有り } \\
\hline 平衡㙨能検查全体 & \multicolumn{2}{|c}{$19.6 \%(19 / 95)$} & $70.5 \%(31 / 44)$ \\
眼 振 & 11.6 & $(11 / 95)$ & 54.5 & $(24 / 44)$ \\
ENG & 16.3 & $(7 / 43)$ & 33.3 & $(10 / 30)$ \\
重心動摇計 & 3.4 & $(1 / 29)$ & 48.3 & $(14 / 29)$ \\
\hline
\end{tabular}

$\square$ : 有効率 $\square$ : 改善率 QR: 治癒率

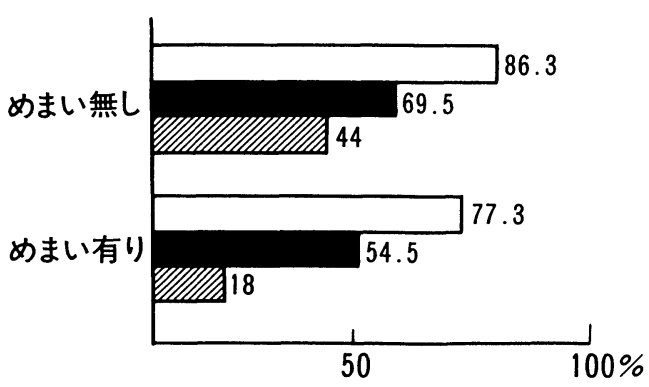

図 4 めまいの有無と聴力回復 
「有効率」 $86.3 \%$,「改善率」 $69.5 \%$ に比較し てやや不良であったが， $\chi^{2}$ 検定では明らかな有 意差は認めなかった。しかし「治癒率」ではめ まい有り群18\%，めまい無し群44\%で，めまい 有り群で不良であり $\chi^{2}$ 検定であ $\mathrm{p}<0.01$ で有 意差を認めた（図 4). また，めまい有り群44 例について，退院時にめまいの残存したものが 8 例（18\%）あり, 回転性めまい 7 例, 非回転 性めまい 1 例であり, 聴力回復は治癒 1 例, 著 明回復 2 例, 回復 1 例, 不変 4 例で, 定義によ り「有効率」50\%，「改善率」37.5\%,「治癒率」 12. $5 \%$ であった。

7. SGB の有無による治療成績では, 聴力 改善関する「有効率」で, めまい有り群では $\mathrm{SGB} \oplus$ 群 $82.6 \%, \mathrm{SGB} \ominus$ 群 $71.4 \%$, めまい無し 群でも $\mathrm{SGB} \oplus$ 群89.1\%, $\mathrm{SGB} \ominus$ 群83.7\%で,

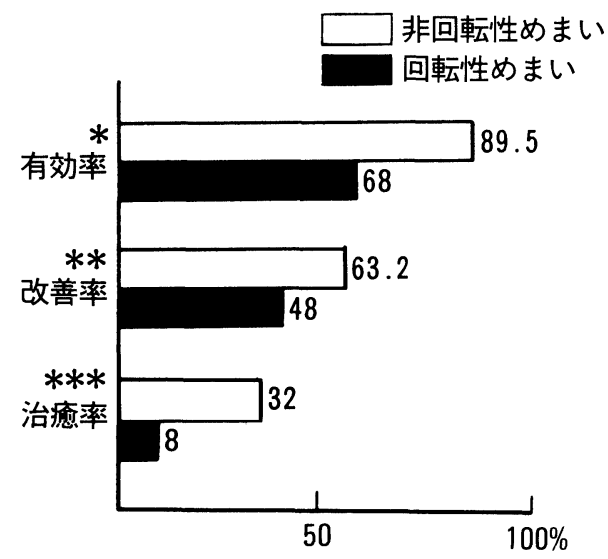

図 5 めまいの性質之聴力回復 非回転性めまいは19耳，回転性めまいは25耳である。

* 10dB以上聴力回復が認められたもの

** 30dB以上聴力回復が認められたもの

*** 平均聴力が $20 \mathrm{~dB}$ 以内に回復したもの

表 3 平衡機能検査所見の有無之聴力回復

\begin{tabular}{|c|c|c|}
\cline { 2 - 3 } \multicolumn{1}{c|}{} & $\begin{array}{c}\text { 所見有り } \\
(31 \text { 耳) }\end{array}$ & $\begin{array}{c}\text { 所見無し } \\
(13 \text { 歹 })\end{array}$ \\
\hline 有効率 $^{*}$ & $\begin{array}{c}74.2 \% \\
(23 / 31)\end{array}$ & $\begin{array}{c}84.6 \% \\
(11 / 13)\end{array}$ \\
\hline 改善率 $^{* *}$ & $\begin{array}{c}51.6 \% \\
(16 / 31)\end{array}$ & $\begin{array}{c}61.5 \% \\
(8 / 13)\end{array}$ \\
\hline
\end{tabular}

* $10 \mathrm{~dB}$ 以上聴力回復が認められたもの

** $30 \mathrm{~dB}$ 以上聴力回復が認められたもの
めまい有り群, 無し群ともに $\mathrm{SGB} \oplus$ 群の有効 性がやや高く認められたが, $\chi^{2}$ 検定では有意差 は認められなかった。

8. めまいの性質では，回転性めまいでは聴 力改善についての「有効率」68\%,「改善率」 $48 \%$ で，非回転性めまいの聴力改善についての 「有効率」89.5\%，「改善率」63.2\%に比較し て不良であったが，回転性めまい，非回転性め まいともに SGB の有無による聴力改善の治療 成績に有意差は認めなかった（図 5 ).

9. めまい有り 44 耳について平衡機能検査所 見の有無之聴力回復をみると, 平衡機能検査全 体で異常所見有りの「有効率」(聴力改善につ いて回復以上） $74.2 \%$ ，「改善率」(聴力改善に ついて著明回復以上） $51.6 \%$ ，「治癒率」 $16 \%$ で，異常所見無しの「有効率」 $84.6 \%$,「改善 率」 $61.5 \%$,「治癒率」 $23 \%$ に比較してやや不 良であったが, $\chi^{2}$ 検定では明らかな有意差を認 めなかった（表 3 ）.

\section{考察}

突発性難聴におりる聴力回復に前庭症状の有 無が関与するか否かについて立木 ${ }^{3)}$ ，山崎 ${ }^{4)}$, 生駒5) らのように関連性がないという報告もあ るが，自覚症状としてのめまいの性質や各種の 他覚的平衡機能検査の結果について分析し, あ るいは経時的に観察した結果, 前庭症状の有無 や眼振の程度と持続時間, また温度眼振検査の 異常などは聴力回復に関与するという報告む 多い.

今回われわれは突発性難聴の患者を発症時あ るいは入院時のめまいの有無で 2 群に分け，各 群の平衡機能検査所見や治療成績の結果から以 下について考察を行った。

1. 自覚的めまいの有無が聴力予後に関与す るか

宮崎ら ${ }^{6)}$ は, 発症時のめまい有り群80例之め まい無し群120例について検討し,めまい有り群 の「改善率」は38.8\%で，めまい無し群の 60.8 \%に比較して統計学的に有意に不良であったと 報告し，吉田 $ら^{7)}$ あ「有効率」について，めま 
い有り群で42\%，めまい無し群で65. 2\%で，め まい有り群で不良であると報告している。めま いの性質では, 藤林ら ${ }^{8)}$ は回転性めまいの自覚 例やめまい持続時間が 15 日間以上と長い例では 「治瘠率」は低い之報告し, 宮崎 ${ }^{6)}$ 屯「改善 率」について回転性めまい $32.7 \%$, 非回転性め まい $48.4 \%$ で回転性めまいでやや不良であった が，統計学的に有意差はなかったと報告して いる.

われわれの結果で屯, めまい有り群の「有効 率」は77. 3\%, 「改善率」は54.5\%で, めまい無 し群の「有効率」 $86.3 \%$, 「改善率」 $69.5 \%$ に 比較してやや不良であったが $\chi^{2}$ 検定では明ら かな有意差は認められなかった。しかし「治瘾 率」については，めまい有り群で18\%，めまい 無し群で44\%であり $\chi^{2}$ 検定で有意差を認めた. また，めまいの性質では，回転性めまいでは 「有効率」68\%,「改善率」48\%で, 非回転性め まいの「有効率」89.5\%,「改善率」 $63.2 \%$ に 比較して不良であり, めまい自覚の有無は予後 に関与していると思われた。

一方高橋ら ${ }^{9)}$ は, 経過中に一度で屯自発眼振 を認めたものでは自発眼振を認めないものに比 較して聴力回復は不良であったが，自発眼振を 認めたものについて，その $45.5 \%$ あまいを自 覚しておらず, 発症前後のめまい自覚の有無は 聴力回復とは相関しなかったと述べている.

われわれの検討では，先に述べたように「有 効率」,「改善率」については, めまい有り群と めまい無し群の間に $\chi^{2}$ 検定では有意差は認め られなかったが，「治癒率」についてはめまい 有り群で有意に聴力回復不良であった.

2. 平衡機能検査所見と聴力改善の相関につ いて

平衡機能検査について, 高橋ら ${ }^{9}$ は ENGに よる自発眼振を経時的に観察した結果, めまい の有無にかかわらず経過中に自発眼振を認める あのでは, 固定時聴力が $50 \mathrm{~dB}$ 以内に回復し たものが16.7\%, 自発眼振を認めない屯のでは $81.2 \%$ あり,さらに固定時聴力の平均值は自
発眼振を認めるものでは $74.6 \mathrm{~dB}$, 自発眼振を 認めないものでは $40.6 \mathrm{~dB}$ で自発眼振を認め るあので有意に不良であったと報告している. 彼らはまた，視標追跡検査で異常所見を示した あのの $61.5 \%$, 減衰振子様回転検査で異常所見 を示したものの $54.5 \%$ に糖尿病, 高血圧, 両側 性難聴などの中枢障害を示唆する疾患の合併率 が高いが予後に関しては正常例と著しい差は認 めなかったと述べている。

また藤林ら ${ }^{8)}$ は, 注視眼振や頭位眼振の有無 により 4 段階に分け検討したところ, 経過中眼 振の程度が悪化した 7 例のうち 5 例が予後は不 変であり,さらにめまいの有無と眼振の有無を 組み合わせて 4 群に分けたところ，「治瘾率」 についてめまい, 眼振ともに有りでは $0 \%$, め まい無し，眼振有りでは25\%，めまい有り，眼 振無しでは44\%，めまい，眼振ともに無しでは 50\%で，めまいや眼振を伴う群では予後は不良 であったと報告し, 岩永ら ${ }^{10)}$ 平衡機能検査は 聴力が治瘾にまで回復するか判定する上で有用 であると述べている.

カロリックテストについては, 宮崎ら王は, 眼振 (自発眼振, 頭位眼振) およびカロリック テストで $\mathrm{CP}$ を認めたものを異常所見有りとす ると, 異常所見出現率は回転性めまい自覚群で は $57.1 \%$, 非回転性めまい自覚群では16.1\%で, 回転性めまい自覚群で有意に高かったが，予後 についてはてれらの平衡機能検査所見陽性では 「改善率」36.4\%，陰性で「改善率」40.4\%で 統計学的な有意差は認められなかったと報告し ている.

さらに吉田らマ2 は, 注視眼振の有無, めまい の有無, 温度眼振検査成績の結果を組みあわせ て予後について検討したところ，めまいがあり， 注視眼振を認め, 温度眼振異常例では不变例が 71. $4 \%$ と予後不良であり，逆にめまいが無く， 平衡機能検査で異常を認めないものでは「有効 率」が71. 4\%であり, 平衡機能検査所見陽性の あのは予後不良であると述べている.

われわれの結果でも, めまい有り群の平衡機 
能検査の異常所見出現率は, 全体および個々の 平衡機能検査でもめまい無し群に比較して有意 に高く，とくに平衡機能検査の 1 つでも異常を 認めたものは70.5\%を占めていた. しかし聴力 回復については, 平衡機能検査で 1 つでも異常 所見を認めたものおよび，個々の平衡機能検査 としては眼振と重心動摇計について, めまい有 り群では, 異常所見有りの「有効率」は異常所 見無しの「有効率」に比較してやや不良であっ たが統計学的な有意差は認められず，めまい無 し群や $\mathrm{ENG}$ 検査については, 乙れらの平衡機 能検査所見之聴力回復に相関は認められなかっ た（表 4 ）.

3. 前庭症状を伴う突発性難聴の病因, 病態 について

宮崎6)，藤林ら ${ }^{8)}$ は，めまいを伴う突発性難 聴の予後は不良であることから，めまいを伴わ ないものとは異なった病因を想定し，高橋ら9 は龍型の scale out の症例では強い健側向きの 自発眼振を認め, mumps に合併した聴平衡覚 障害に酷似しており，ウイルス，血管障害など の病因かあるいは病態として内耳障害の程度を 反映していると推定している.さらに高橋らは， 自発眼振の向きは，10日以内では75\%が患側向 きでその後健側向きを示すととから, 突発性難 聴による前庭症状は急性の末梢迷路刺激, 続い て機能低下に由来すると述へ， 宮崎 ${ }^{6)}$, 朴沢 ${ }^{11}$

表 4 平衡機能検査所見およびめまいの有無と聴 力回復

\begin{tabular}{|c|c|c|c|}
\hline & & \multicolumn{2}{|c|}{ 恥力回復 (有効率 $\left.{ }^{*}\right)$} \\
\hline & & めまい有り & めまい無し \\
\hline \multirow{2}{*}{$\begin{array}{l}\text { 平衝譏能検查 } \\
\text { 体 }\end{array}$} & 所見有り & $74.2 \%(23 / 31)$ & $94.7 \%(18 / 19)$ \\
\hline & 無し & $84.6 \%(11 / 13)$ & $84.2 \%(64 / 76)$ \\
\hline \multirow{2}{*}{ 眼 振 } & 所見有り & $(18 / 24)$ & $90.9 \%(10 / 11)$ \\
\hline & 無し & $(16 / 20)$ & $85.7 \%(72 / 84)$ \\
\hline \multirow{2}{*}{ ENG } & 所見有り & $(9 / 10)$ & $100 \% \quad(7 / 7)$ \\
\hline & 無し & $75 \% \quad(15 / 20)$ & $86.1 \%(31 / 36)$ \\
\hline \multirow{2}{*}{ 重心動摇計 } & 所見有り & $71.4 \%(10 / 14)$ & $100 \%(1 / 1)$ \\
\hline & 無し & $86.7 \%(13 / 15)$ & $0 \% \quad(0 / 28)$ \\
\hline
\end{tabular}

* $10 \mathrm{~dB}$ 以上聴力回復か認められたすの
あ同様の報告をしている．また岩永ら得は，治 癒に至らないものでは16例中13例に平衡機能検 査異常を認め, 蝸電図においてより不可逆的な 内有毛細胞の障害が示されたと報告している.

われわれの結果ではウイルス検索などでは病 因を示唆するような所見はなく，全体としてめ まいの自覚や平衡機能検査で所見を認めるもの での予後が不良の傾向を認めたが，統計学的に は明らかな有意差は認められず，前庭症状を伴 う突発性難聴について特別な病因や病態を示唆 する結果はえられなかった。 しかし，突発性難 聴の病態としては内耳の循環障害が考えられて おり，より広範囲の障害として前庭症状を伴う あの之推測される. 従って前庭症状の有無はそ の予後に関与することあ十分に考えられる.

突発性難聴では前庭症状としてのめまいは一 過性であるととが多いが，朴沢ら ${ }^{11}$ はこのよう に前庭症状が一過性であるのは，迷路病態の回 復過程だけでなく中枢性の代償作用によるもの であり，実験的 ${ }^{12213)}$ 亿も支持されていると述べ ている. われわれの検討で屯退院時にめまいの 残存したものは44例中 8 例之少なかったが，聴 力不変が 4 例と予後不良であった. 発症時の状 態から, 突発性難聴の病態は突然に形成される あのであり, 発症時の前庭機能症状を捕えるこ とはその病巣の広がりや病態を知るうえで重要 と思われるが，病態の回復と同時に中枢性の代 償により，前庭機能症状は逐次変化するため平 衡機能検査を行った時期により平衡機能検査結 果と治療成績の相関性が異ってくるてとが予想 される. われわれの検討は入院時に行った前庭 症状の有無や，平衡機能検査所見についての検 討であるが，めまいを自覚したものや平衡機能 検査で異常を認めたものでは, やや聴力回復不 良の傾向を認めた。しかし $\chi^{2}$ 検定では，聴力 回復と平衡機能検査所見との相関性は明らかで はなかった。

従って入院後も経時的に平衡機能検査を施行 することは変化する迷路の状態および，予後を より正確に把握する上で重要と思われる. 


\section{まとめ}

1. 発症時の難聴の程度では, $61 \mathrm{~dB}$ 以上の 高度難聴例がめまい有り群65.9\%で，めまい無 し群の $53.3 \%$ に比較してやや多く認められた.

2. めまいの性質では回転性めまい $56.8 \%$ ， 非回転性めまい $43.2 \%$ であった，回転性めまい の $80 \%$ が発症時高度難聴であった。

3. 平衡機能検査で異常所見を認めたものは, めまい有り群では $70.5 \%$ で，めまい無し群の 19. $6 \%$ に比較して有意に多かった.

4. 聴力回復について，めまい有り群では 「有効率」(10 dB 回復以上) $77.3 \%$,「改善率」 (30 dB 著明回復以上) $54.5 \%$ であり, めまい無 し群の「有効率」 $86.3 \%$, 「改善率」 $69.5 \%$ に 比較して不良であったが, $\chi^{2}$ 検定では有意差を 認めなかった。しかし「治癒率」については， めまい有り群18\%, めまい無し群44\%で $\chi^{2}$ 検 定で有意差を認めた.

5. めまいの性質之の関連をみると, 回転性 めまいでは「有効率」68\%で, 非回転性めまい の89.5\%に比較して聴力回復は不良であった.

6. 退院時にめまいが残存していた症例の 「有効率」は50\%と聴力回復不良であった.

7. 平衡機能検査所見の有無については, め まい有り群では所見有りの「有効率」74.2\%, 「改善率」51.6\%で，所見なしの「有効率」84.6 $\%$ ，「改善率」 $61.5 \%$ に比較してやや不良であ ったが， $\chi^{2}$ 検定では聴力改善について有意差 を認めなかった。

本論文の要旨は第16回日本臨床耳科学会に打いて発 表した。

\section{引用文献}

1）鰐㴊伸子, 石塚洋一, 木村元俊, 他: 当科におけ る突発性難聴の治療成績. 耳鼻臨床 $82: 189 \sim$ 197, 1989.
2 ) 前田秀彦 : 高度難聴児の平衡機能の発達に関する 研究一重心動摇検査による定量的検討一. 帝京医 学雑誌 $10: 171 \sim 180,1987$.

3）立木 孝: 所謂「突発性難聴」の統計的観察. 日 耳鼻 $72: 1628,1969$.

4) 山崎芳樹 : 突発性難聴の前庭機能に就いて. 耳鼻 $4: 149,1958$.

5 ）生駒尚秋：神経耳科学的立場から見た突発性難聴 之前庭神経炎. 耳鼻 $18 ： 401 ， 1972$.

6 ）宮崎為夫，瀧口哲也，大尾嘉宏巳，他：めまいを 伴う突発性難聴の統計的観察. 耳鼻臨床 $80: 715$ $\sim 721,1987$.

7 ）吉田昭男, 岡本 健 : 平衡機能検査よりみた突発 性難聴の予後. 耳喉 $49:$ 521 525, 1977.

8) 藤林慶子, 瀧本 勲, 稲福 繁: 突発性難聴一平 衡障害との関連について一. 耳鼻臨床 $78: 1270$ $\sim 1276,1985$.

9）高橋正紘, 神崎 仁, 猪 忠彦: 突発性難聴の予 後之平衡機能検查所見一自発眼振, 減衰振子様回 転検査, 視標追跡検查所見を中心に一. 耳鼻臨床 $67: 541 \sim 555,1974$.

10）岩永迪孝, 山本悦生 : 突発性難聴の予後判定一平 衡機能検查, 蝸電図法を指標とする観察一. 耳鼻 臨床 $74: 411 \sim 425,1981$.

11）朴沢二郎：突発性難聴患者の平衡機能一特に迷路 が障害される過程と平衡機能検查の回復する過程 についてー. Audiology Japan 13:150, 1970.

12) McCabe : A consideration of some physiological principles in the surgical treatment of Meniere's disease. Ann Otol $67:$ 978, 1958.

13) Flurr $E:$ Vestibular compensation after labyrinthine destruction. Acta Otolaryngol $52: 367$, 1960 .

$\left(\begin{array}{l}\text { 原稿受付 : 平成元年 } 6 \text { 月 } 23 \text { 日 } \\ \text { 原稿採択 : 平成元年 } 8 \text { 月 } 1 \text { 日 } \\ \text { 別刷請求先 : 鱚㴊伸子 } \\ \text { Ү213 川崎市高津区溝口74 } \\ \text { 帝京大学医学部耳鼻咽喉科学教室溝口病院 }\end{array}\right)$

